\title{
Influence of Marine Security on Exploitation of Blue Economy Resources: A Case of Mombasa County, Kenya
}

\author{
Sammy N. Njiru*, Joseph M. Mutungi, Duncan Ochieng \\ Africa Nazarene University, Kenya
}

*Corresponding Author: Sammy N. Niiru, Africa Nazarene University, Kenya

\begin{abstract}
The concept of blue economy is as old as the invention of water transport but its mainstreaming in the formal economies of many states, particularly the developing countries has only become eminent in the last two decades. The security of resources and actors in the blue economy is a major issue that must be taken into account if states are to reap the benefits in this sector. This study focused on assessing security challenges in the Indian Ocean waters and efforts made by the government of Kenya to assure secure and sustainable exploitation of the resources therein. Pollution and piracy were found to be major challenges militating against exploitation of maritime resources while efforts at development, adoption and enforcement of an enabling legal and policy framework were found to be work in progress. The study argues that Kenya must expedite institutionalization and mainstreaming of the blue economy support systems for the country to gain maximum benefits from the emergent opportunities in the sector.
\end{abstract}

Key words: maritime, security, blue economy, pollution, regulatory framework

\section{INTRODUCTION}

There exist a vast array of sectors that individuals, groups and states alike pool resources in order to exploit and build their economic portfolios. One of such sectors is the blue economy, a sector which has defied a unified definition. It is for this reason that this study espouses blue economy as a compound concept that describes the broad range of economic endeavors and enabling legal and policy frameworks that are grounded in oceanic resources. Among the many components of the blue economy are the fisheries industry, tourism, maritime transport and offshore renewable energy drilling. The significance of the blue economy is best captured by Commonwealth Secretariat's (2019) assertion that the sector accounts for 350 million fisheries jobs globally. The International Maritime Organization (IMO) (2019) further approximates that $90 \%$ of global trade is transported by sea, shedding more light on the pride of place the blue economy occupies in the global economy parlance.

The foregoing statistic simply that sustainable exploitation of the oceanic resources must be the norm rather than the exception in both developed and developing countries and this places maritime security at the core of international security programming. Barros and Hespen (2013) contend that the concept of maritime security draws the international community's attention to oceanic resources and how they must be protected to benefit present and future generations. Yet, the term 'maritime security' remains a nebulous concept with no concrete universally accepted definition of what it means. This study is persuaded and thus adopts Feldt, Roell and Thiele's(2013) exposition of marine security as a combination of preventive and responsive security measures intended to safeguard the maritime domain against threats and intentional unlawful acts. Marine security challenges and or lapses have been experienced in different parts of the world. South American countries like Venezuela, Colombia and Brazil know too well the problem of maritime insecurity owing to the numerous challenges their seafarers and those working in their coastlines experience regularly. Among the major documented challenges these countries have had to contend with include kidnappings, drug trafficking and piracy (Clark, 2018). The challenges compares to those of studies conducted in the East and Horn of Africa by Omondi (2017) and Long'iro and Maluki (2017).These kind of challenges notwithstanding, this study concurs with Roberts (2015) that states with access to water bodiesare at a vantage point in terms of addressing problems associated with unemployment and poverty, poor growth and food insecurity if they effectively harness and manage their blue economies. 
A study by Wenhai et al. (2019) on China's blue economy indicates the adverse effects of pollution on the sustainability of the maritime resources. Micro plastics were found to undermine marine tourism, fishing among other economic ventures in the marine environment. This led to the government's development and strict enforcement of the regulatory regime including ensuring treatment of effluent. Klinger et al. (2018) argues that implementation of pollution control mechanisms across the globe remain inadequate due to poor understanding of the integrated management of multiple economic sectors which converge in the blue environment. Off Africa's west coast the Gulf of Guinea, the coastal zone that stretches from Senegal to Angola, provides an economic lifeline (energy production and the fishing industry) to both the littoral and landlocked countries in the region. However, insecurity of the coast waters in the form of piracy threaten the region's blue economy. Instructively, these studies focus on pollution as the major threat to the blue economy, neglecting other aspects such as piracy and terrorism as well as over exploitation of resources.

Kenya is endowed with vast aquatic resources thus presenting a big opportunity for boosting its blue economy's growth while supplementing the traditional segments of the larger economy through creation of employment opportunities, alleviating poverty, enhancing food security, and supplementing other industries (UNDP, 2018).Muigua (2018), however points out that the country's blue economy is greatly underexploited and that the viability of Kenya's blue economy is greatly hindered by a number of challenges such as poor policies and infrastructure, dynamics which contribute to maritime insecurity.It's only in 2019 that Kenya established the Kenya Coast Guard Unit to complement the work of the Kenya Navy in securing the marine environment in general and the resources and legal activities in particular there in. However, it's noteworthy that these security agencies seem to be only situated in the coast, neglecting other vital water bodies that contribute to the blue economy.

\section{Problem And ObJective}

The relationship between economics and security is a critical one. The integration between these factors implies that Kenya's economic performance dependson its security stability (Retter, Frinking, Hoorens, Lynch, Nederveen\& Phillips, 2020).The country's territorial waters have remained inadequately secured and consequently the resources therein underexploited. Insecurity concerns in Kenya's territorial waters include seaborne terrorism, piracy, pollution of the marine environment, and inconsiderate, careless and unsustainable harvesting of marine resources like fish (Randrianantenaina, Fanning, Williamson \&Bailet, 2013).Despite all these issues, there are pointers and indicators that maritime security in Kenya's territorial waters and the influence it has on the country's blue economy remain largely under-researched. The existing few researches such as that carried out by Thadeus (2013), are only limited to piracy as a concern area. It is for this reason that this study sought to assess the influence of maritime security on exploitation of Kenya's blue economy resources.Specifically, the study sought to identifythe capabilities and existing gaps in the current maritime security architecture that undermine the growth and performance of the country's blue economy.

\subsection{Theory}

The study was anchored on the Copenhagen school's securitization theory developed by Barry Buzan, Ole Wever and Jaap de Wilde in the mid-1990s. The proponents of this theory hold that ordinary issues are securitized when they are articulated as extreme threats that need to be dealt with urgently(Stritzel, 2014).For instance, fishing may be a normal everyday occurrence. However, if an individual or group of individuals considers an aspect of the act such as overfishing a 'security threat' and start advancing their views on the same, then overfishing shifts from being a low priority concern to a high priority issue that requires appropriate security action like issuing policy guidelines criminalizing catching of fingerlings and prescribing penalties for offenders, regulating the size of fishing nets holes or even the deployment of security agents to enforce the policy. The proponents of this theory have largely focused on five sectors namely economic, societal, military, political and environmental sectors. In the context of this study, this theory relates various activities which in some instances may be taken as normal non-security items and presents them as serious security issues which must be attended to in an effort to secure the marine environment and the economic activities that take place there. For instance, pollution of the marine environment which for a long time 
Influence of Marine Security on Exploitation of Blue Economy Resources: A Case of Mombasa County, Kenya

remained a non-concern issue has in the recent years become a major security concern due to its securitization by different players like politicians, security professionals and environmentalists.

\section{Methodology}

This study employed a descriptive research design with the survey approach being taken to answer the questions what, when, where and how maritime security influences exploitation of blue economy resources within Kenya's territorial waters. To answer these questions both quantitative and qualitative techniques were used to investigate the relationship between the variables of the study. Precisely, the study was conducted along the Kenyan coastal county of Mombasa which plays host to a broad range of blue economy industries and allied infrastructure such as the port. The study targeted the local indigenous and migrant population which is directly and heavily dependent on the Indian Ocean for their sources of livelihoods. Various state officials were also incorporated. From this population, a sample size of 384 respondents was obtained whose distribution was as shown in Table 1.

Sample Size

\begin{tabular}{|l|l|}
\hline Respondent Segment & Sample Size \\
\hline Director General, Kenya Coast Guard Service & 1 \\
\hline Commander, Kenya Navy & 1 \\
\hline PS, State Department for Fisheries, Aquaculture and the Blue Economy & 1 \\
\hline PS, State Department for Maritime and Shipping Affairs & 1 \\
\hline PS, State Department for Tourism & 1 \\
\hline PS, State Department for Environment and Forestry & 1 \\
\hline Kenya Maritime Authority top leadership & 2 \\
\hline Mombasa County Executive Committee members in charge of trade and tourism & 2 \\
\hline Members of the public (Adult population) & 374 \\
\hline Total & $\mathbf{3 8 4}$ \\
\hline
\end{tabular}

Source: Researcher, (2020)

Simple random sampling was used to obtain the members of the public from among the adult population in the county while the state and county government officials were purposively obtained based on the assumption that by virtue of their official positions, they held vital information critical to the study. A questionnaire comprising of closed and open-ended questions was used to obtain information from the members of the public segment of the sample while in-depth interviews were conducted on the state and county government officials. To ensure that the respondents from the county were represented in the study, the 30 wards comprising the county were visited, with the exception of Kongowea ward where the pilot study was conducted. From each of the remaining 29 wards, approximately 13 individuals from the general public were approached and requested to take part in the survey (to achieve the figure of 374 the researcher engaged 12 people in some wards). Respondents from the wards who agreed to participate in the survey were brought together in a common meeting place and after which they were briefed about the study and the objectives of the study explained to them. Those who consented to take part in the study were issued with questionnaires given ample time to complete them. The entire data collection process was conducted in a systematic manner to enhance the quality of responses obtained from the survey participants and also to ensure that all the data collection instruments were fully answered and received back from the survey participants.

After data collection, the process of data analysis began with inspecting and cleaning the data. This was followed by coding of the questions and keying them into the Statistical Package for Social Sciences (SPSS) software (version 23) for analysis purposes. Frequency distribution and percentages were used to transform the quantitative data into useful information. Content analysis was undertaken on the qualitative data and this involved reformulation of accounts presented by the interviewees taking into perspective the context, position and experiences of each respondent. The outcomes of the analysis have been presented in tables and verbatim to enhance clarity and descriptions of the items under investigation.

\subsection{Analysis and Discussion of Findings}

Out of the 374 questionnaires that were administered, 355 were returned, fully filled representing a return rate of $95 \%$. All the planned interviews with state and county officials were also conducted as 
scheduled. According to Lavrakas (2008), a response rate of at least $60 \%$ is adequate and an indicator of success in data collection. This response rate was acceptable for analysis since, the whole point of conducting a survey is to obtain useful, reliable, and valid data in a format that makes it possible to analyse and draw significant conclusions about the target population.

The study sought to establish some of the main causes of marine pollution in the region, its effect on economic activities within the marine environment and adequacy of the measures put in place to counter it. Based on these questions, numerous causes of marine pollution in Mombasa Countywere identified by the respondents. Disposal of plastic wastes was found to be the most mentioned cause of pollution $(82 \%)$ followed by discharge of effluents by local industries $(80 \%)$ into the ocean. Other causes of marine pollution that came up from the responses included oil spillage from water vessels (77\%), agricultural effluents from nearby and far away farms (66\%), and abandoned fishing gear (61\%). These sources of pollution were found to significantly affect the viability of the study area's blue economy activities, particularly fishing and water sporting. Pollution was further found to increase the chances of diseases that negatively affected reproduction and productivity. The findings further demonstrated that oil spillage from the marine vessels could get on to the gills and feathers of marine animals thus making it difficult for them to move properly or feed their young ones thereby affecting their reproduction and in extreme cases resulting into deaths, sometimes in large scale, of the affected animals. The health of both human and the aquatic animals were also found to be affected by pollution of the water body. For instance, it was established that when some of the animals ingested the chemicals disposed in the ocean and then eaten by human beings, the toxins in the chemicals consumed by the animals were transferred to humans who had eaten such animals' products, leading to ailments such as cancer, birth defects and other health problems. Cumulatively, the blue economy was thus gradually but steadily adversely affected by pollution.

Research results presented in Table 4.4 highlight views on marine safety and exploitation of blue economy resources. The question on creation of environment for tourism to thrive through good pollution-free marine environment show that majority of the respondents replied positively to this question with $24 \%$ strongly agree and a further $64 \%$ agreeing that such an environment was critical for tourism to thrive in Mombasa County. $49 \%$ of the respondents disagreed that adequate antipollution measures had been instituted to protect marine environment and make it more attractive to economic activities such as tourism. The indifferent $6 \%$ was considered important because it could swing the final findings if they were to take the view of those agreeing. Three quarters of the respondents $(74 \%)$ agreed that concerted government efforts were necessary in protecting both the quality and quantity of the food resources accruing to the country from the ocean. This finding came against a backdrop of another response where 59\% of the respondents were of the view that the government of Kenya had not put in place good emergency response administration facilities and personnel to secure the marine environment. A further $74 \%$ of the respondents pointed towards government ineffectiveness in responding to accidents and disasters in the ocean citing recent accidents along the Likoni channel which had tentatively stopped/interfered with the transport sector of the economy.

Table4.4. Marine Safety and Exploitation of Blue Economy Resources

\begin{tabular}{|c|c|c|c|c|c|}
\hline & 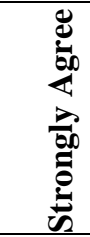 & 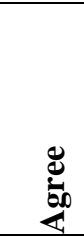 & & 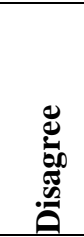 & 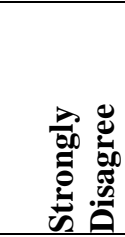 \\
\hline $\begin{array}{l}\text { Pollution-free marine environment creates a good environment for } \\
\text { tourism to thrive. }\end{array}$ & $24 \%$ & $64 \%$ & $5 \%$ & $5 \%$ & $2 \%$ \\
\hline $\begin{array}{l}\text { Anti-marine pollution measures have put in place to ensure that the } \\
\text { ocean is attractive to tourists. }\end{array}$ & $14 \%$ & $31 \%$ & $6 \%$ & $41 \%$ & $8 \%$ \\
\hline $\begin{array}{l}\text { To enhance the quality and quantity of marine food fished in the } \\
\text { ocean the government needs to ensure that pollution of the ocean is } \\
\text { very minimal. }\end{array}$ & $47 \%$ & $27 \%$ & $3 \%$ & $12 \%$ & $11 \%$ \\
\hline $\begin{array}{l}\text { In my view the government of Kenya has put in place good } \\
\text { emergency response administration facilities and personnel to } \\
\text { secure the marine environment at the coast. }\end{array}$ & $4 \%$ & $16 \%$ & $21 \%$ & $40 \%$ & $19 \%$ \\
\hline
\end{tabular}


Influence of Marine Security on Exploitation of Blue Economy Resources: A Case of Mombasa County, Kenya

Government response have been effective in addressing accidents $4 \%$ and disasters that have in the past occurred in the country's territory of the Indian Ocean.

\section{Source: Field Data (2020)}

An analysis of the responses from the open ended questions in light of the measures put in place by the government to enhance marine security and consequently boost the blue economy indicated the presence of the Kenya Navy, the establishment and actualization of the Kenya Coast Guard Service (KCGS), establishment of offices by key government entities such as the National Environment Management Authority (NEMA) and the Kenya Maritime Authority (KMA) institutions which are supposed to superintend the operations of the marine environment on behalf of the state.

Interviewees from the State Departments for Fisheries, Aquaculture and the Blue Economy, Tourism and the Environment and Forestry were the most vocal and most passionate about the need to address pollution related matters. The respondents concurred that despite measures being put in place especially to curb pollution, adherence and compliance to these measures by the general public remained a big challenge. This subsequently affected the overall contribution of the marine resources to the national economy. An interviewee had the following to say in this regard:

For the blue economy in this region to thrive, both the government and the general public must play their roles in ensuring that the policies and measures put in place are successful, especially in curbing pollution which has become a menace of sorts. So far this has not been successful. Though there are government anti-pollution policies, their implementation has been weak and hence they have not yielded the expected results. Pollution of the ocean still remains rife. The impact of this has been decline in the volume of economic activities related to the ocean such as fishing and sporting activities. [Interviewee 3]

Besides affecting the marine life, pollution was also found to negatively affect tourism activities at the Kenyan coast. As a result of dying marine animals and plants, the attractiveness of the coastal scenery was rapidly diminishing. Tourists were thus found to be increasingly compelled to go to national parks in the hinterlands. The net effect is that the income of the coastal economy generated directly from tourism activities significantly reduces.

As experienced during the recent accident that occurred at the Likoni ferry in 2019 when a woman and her daughter lost their lives, the inability of the government to carry out the rescue operation and the inability of the of KMA and the relevant security agencies to retrieve the sunken vehicle and the victims of the accidents laid bare the government's poor emergency response administration. Additionally, the fact that assistance from outside to retrieve the vehicle and the accident victims brought to fore the capability gaps of the government agencies charged with securing the marine environment. These failures and inadequacies have the potential to negatively affect the region's blue economy beyond what is being currently experienced. The following is an observation by one of the interviewees:

The effects might not be pronounced and very obvious for everyone to see, but from where I sit poor emergency response to accidents and emergencies dissuade potential investors from engaging in the economic opportunities in the marine environment. Quite honestly, many accidents occur in the marine environment and not all are covered by the media, so the public does not understand the depth of under preparedness to respond to such issues and their net effect on the hitherto economic activities. [Interviewee 8]

The legal and policy framework guiding the protection and exploitation of marine resources was found to be weak, although it was reported that reviews were currently underway. The major challenge of the current legal and policy regime was found to be the scope of economic activities and the presence of actors with overlapping responsibilities yet uncoordinated to improve on the collective performance. Piracy was reported to persist along the coast despite efforts by the security agencies responsible, although this was happening along the marine borders of Kenya. An interviewee had the following to say in this regard:

The problem of piracy persists and this continues to undermine operations in the ocean. Small scale fishermen using unsophisticated fishing equipment have borne the brunt of such attacks 
and this has tended to discourage them from venturing deep into the countries territorial waters, thus denying them an opportunity to benefit from the states marine resources abundance. (Interviewee 1)

From the findings presented in the foregoing paragraphs, this study contends that the wellbeing and performance of the blue economy at the Kenyan coast and indeed the country as a whole is dependent on the safety and security of the country's territorial waters, which this study found to be polluted and hence not fully supportive of the economic activities therein. The many factors that were identified as causes of marine pollution at the Kenyan coast which include inflow of chemicals as a result of industrial and agricultural effluents, solid waste such as plastics, man-made sedimentation, and oil spills all affect the quality of marine resources. This in effect negatively affects the blue economy in a number of ways. Accumulation of plastic waste at the shores and even on-shore renders these places unattractive for tourism activities. Additionally, such plastic wastes lead to death of sea life such as fish which traders rely on for their livelihoods. Pollution in the water bodies also damaging food supply, a critical pillar of not just the blue economy but also human life. In summary, the key areas negatively affected by marine pollution are public health, tourism, fisheries and real estate among others. The study findings are in line with that of Wenhai et al. (2019) who determined that marine pollution, when not controlled, has the potential of bringing the blue economy to its knees. Raubenheimer and McIlgorm, (2018) and Cole et al. (2011) in their different studies also established that pollution of the marine ecosystem diminishes the sustainability of the blue economy. That majority of the respondents in this study were of the opinion that enough efforts and resources have not been dedicated by the government and other stakeholders in addressing pollution implies that if the situation continues getting worse, the entire blue economy could be brought down and this is highly likely to have immense negative impact on the country's economy as a whole.

The preparedness and capability of the KMA and other state agencies in addressing emergency issues that might occur in the country's territorial waters was also put to question as the majority of the respondents, citing recent events were convinced of their inability. This finding is supported by that of Ishak and Johari (2019) who averred that emergency response to marine disasters tend to be poor in the less developed countries, of which Kenya is categorised as such a nation. Strengthening the engagement of the private players such as the business organizations and even individual traders in enhancing emergency response is a highly desirable undertaking as expressed in the findings of the study. This study recommends that the government needs to take the blue economy more seriously and allocate to the department adequate resources that will allow it enhance its human and equipment capacity and capability to effectively secure the marine environment. This can be further achieved by instituting public-private partnerships to develop and foster emerging technologies, practices and information that would enhance joint actions in the protection and sustainable exploitation of the resources. Such efforts would go a long way in securing and boosting Kenya's blue economy for it to make its rightful contribution to the national economy.

\section{CONCLuSion}

Kenya is endowed with vast marine resources which if properly secured and exploited can immensely contribute to the national economy. Though efforts have been made by the state to ensure sustainable exploitation, problems of insecurity persist and this undermines the sector's attractiveness to investors. It is therefore imperative that all actors in the blue economy space, both public and private demonstrate unity of purpose in marshalling the requisite resources for the country to benefit from her natural wealth in the waters.

\section{REFERENCES}

[1] Barros, A. S.,\&Hespen, I. V. (2013). Maritime Security: Current Challenges. Leuven Centre for Global Governance Policy Briefs. Leuven, Belgium: KU Leuven - Leuven Centre for Global Governance Studies. Policy Brief No. 20 - June 2013.

[2] Clark, X. (2018). South America: Rising Concerns Over Maritime Security. Retrieved on $23^{\text {rd }}$ May 2020 from https://www.controlrisks.com/our-thinking/insights/newsletters/maritime-newsletter-may2018/south-america-rising-concerns-over-maritime-security

[3] Feldt, L., Roell, P.,\& Thiele, R. D. (2013). Maritime Security - Perspectives for a Comprehensive Approach. ISPSW Strategy Series: Focus on Defence and International Security, 222, pp. 1 - 25. 
Influence of Marine Security on Exploitation of Blue Economy Resources: A Case of Mombasa County, Kenya

[4] International Maritime Organization (2008). IMO Maritime Security Policy Background Paper. Sixteenth OSCE Economic and Environmental Forum - Part 1.

[5] International Maritime Organization (2019). Overview. Retrieved on $28^{\text {th }}$ May 2020 from https://business. un.org/en/entities/13

[6] Klinger, D., Eikeset, B., Davíðsdóttir, A., winter, M., \& Watson, J. (2018). The Mechanics of Blue Growth: Management of Oceanic Natural Resource Use with Multiple, Interacting Sectors. Marine Policy, 87, pp.356-362.

[7] Lavrakas, P. J. (2008). Encyclopaedia of survey research methods (Vols. 1-0). Thousand Oaks, CA: Sage Publications.

[8] Long'iro, M. J. \&Maluki, P. (2017). Maritime Security in East Africa: The Role of International and Regional Instruments. Unpublished Master's Thesis, University of Nairobi, Kenya.

[9] Muigua, K. (2018). Harnessing the Blue Economy: Challenges and Opportunities for Kenya. http://kmco. co.ke/wp-content/uploads/2018/12/Harnessing-the-Blue-Economy-Challenges-and-Opportunities-forKenya-24th-December-2018.pdf

[10] Omondi, J. C. (2017). Improving Maritime Surveillance Kenya's Remote Coastal Islands: Application of Renewable Energy Solutions. World Maritime University Dissertations. 569.https://commons.wmu.se/cgi/ viewcontent.cgi?referer=https://www.google.com/\&httpsredir=1\&article=1568\&context=all_dissertations

[11] Randrianantenaina, J. E., Fanning, L., Williamson, H. G. \&Bailet, F. (2013). Maritime Piracy and Armed Robbery Against Ships: Exploring the Legal and the Operational Solutions. The Case of Madagascar Available at: https://www.un.org/Depts/los/nippon/unnff_programme_home/fellows_pages/fellows_pap ers/Randrianantenaina_1213_Madagascar.pdf

[12] Raubenheimer, K., and McIlgorm, A. (2018). Can the Basel and Stockholm Conventions Provide a Global Framework to Reduce the Impact of Marine Plastic Litter? Marine Policy, 96, pp.285-290.

[13] Retter, L., Frinking, E. J., Hoorens, S., Lynch, A., Nederveen, F. \& Phillips, D. W. (2020). Relationships Between the Economy and National Security: Analysis and Considerations for Economic Security Policy in the Netherlands. https://www.rand.org/content/dam/rand/pubs/research_reports/RR4200/RR4287/ RAND_RR4287.pdf

[14] Roberts, J. (2015). The Blue Economy: From Concept to Reality in the Caribbean Region. Discussion paper for the Caribbean Regional Dialogue with the G20 Development Working Group.

[15] Stritzel, H. (2014). Securitization Theory and the Copenhagen School. In: Security in Translation. New Security Challenges Series. Palgrave Macmillan, London.

[16] Thadeus, W. J. (2013). The Effect of Somali Piracy on Kenya's Maritime Sector. Unpublished Master's Thesis, University of Nairobi, Kenya.

[17] UNDP (2018). Leveraging the Blue Economy for Inclusive and Sustainable Growth. https://www.Oceana ctionhub.org/leveraging-blue-economy-inclusive-and-sustainable-growth

[18] Wenhai, L., Cusack, C., Baker, M., Tao, W., Mingbao, C., Paige, K., et al. (2019). Successful Blue Economy Examples with an Emphasis on International Perspectives. Frontiers in Marine Science, 6(261).

Citation: Sammy N. Njiru, Joseph M. Mutungi, Duncan Ochieng. "Influence of Marine Security on Exploitation of Blue Economy Resources: A Case of Mombasa County, Kenya" International Journal of Humanities Social Sciences and Education (IJHSSE), vol 7, no. 10, 2020, pp. 94-100. doi: https://doi.org/10.20431/2349-0381.0710012.

Copyright: (C) 2020 Authors. This is an open-access article distributed under the terms of the Creative Commons Attribution License, which permits unrestricted use, distribution, and reproduction in any medium, provided the original author and source are credited. 